\title{
ABIOTIC PHOTOSYNTHESIS OF SUBSTANCES RELATIVE TO THE ORIGIN OF LIFE FROM AQUEOUS AMMONIUM CARBONATE SOLUTIONS
}

\author{
SORIN KIHARA, MITSUO SANADA, SHINJI KUWADA, YOSHIKI SOHRIN, OSAMU SHIRAI, HISAO \\ KOKUSEN, MITSUKO SUZUKI and MASAKAZU MATSUI
}

Institute for Chemical Research, Kyoto University, Uji, Kyoto 611, Japan

\begin{abstract}
It has been demonstrated that amino acids and nucleic acid bases can be synthesized by UV irradiation even in such rather oxidizing atmosphere as aqueous solutions containing $\mathrm{CO}_{2}, \mathrm{HCO}_{3}{ }^{-}$and/or $\mathrm{CO}_{3}{ }^{2-}$ in the absence of $\mathrm{CH}_{4}$ or $\mathrm{H}_{2}$. For the production of amino acids and nucleic acid bases from ammonium carbonate solution or water to which $\mathrm{CO}_{2}$ and $\mathrm{NH}_{3}$ gases had been dissolved, UV shorter than $250 \mathrm{~nm}$, temperature higher than $80^{\circ} \mathrm{C}$ and the coexistence of $\mathrm{Mg}^{2+}$ were found to be effective. On the basis of some experimental evidences, oxalic acid and/or oxamic acid are assumed to be the possible intermediates for the synthesis.
\end{abstract}

Key words Photosynthesis, Amino acids, Nucleic acid bases, Ammonium carbonate, Intermediates

Since the synthesis of amino acids from $\mathrm{CH}_{4}, \mathrm{NH}_{3}, \mathrm{H}_{2}$ and $\mathrm{H}_{2} \mathrm{O}$ by Miller[1], wide variety of molecules of importance for the origin of life have been produced from mixtures of nonbiological substances with the aid of various energy sources. The mixtures adopted in most of previous works have been those which provide reducing atmosphere[2]. However, Judging from the oxidizing compositions of volcanic gases[3] and airs on Venus or Mars[4] and the geochemical estimations $[5,6]$ based on the buffer actions of silicates or carbonates, it is fair to consider that the air on the primitive earth had been rather oxidizing and contained $\mathrm{CO}_{2}$ instead of $\mathrm{CH}_{4}$.

In the present paper, the photosyntheses of amino acids and nucleic acid bases from aqueous ammonium carbonate solutions or water into which $\mathrm{CO}_{2}$ and $\mathrm{NH}_{3}$ had been dissolved are introduced and the processes for the syntheses are discussed. In connection with the present subject, Paschke et al.[7] synthesized glycine by $\alpha$-ray irradiation of solid ammonium carbonate and Abelson[8] formed several kinds of amino acids in gaseous mixtures of $\mathrm{CO}_{2}$ or $\mathrm{CO}, \mathrm{N}_{2}$ or $\mathrm{NH}_{3}, \mathrm{H}_{2} \mathrm{O}$ and $\mathrm{H}_{2}$. Oro' et al.[9] reported the production of amino acids in a heated aqueous solution of formaldehyde and hydroxylamine and gave an interpretation of the synthesis. The group of Egami pointed out the important role of transition elements $[10,11]$ in the synthesis of amino acids and peptides in the Oro's system, and found the formation of glycine and alanine from various sugars and ammonia in a modified sea water which contains various transition elements[12].

\section{EXPERIMENTAL}

A high pressure mercury arc lamp (H400-P, product of Toshiba Co. Ltd.) of which spectrum distributes between 230 and $600 \mathrm{~nm}$ was used as a light source. The quantity of light irradiated (dose-rate) was determined by a uranyl oxalate actinometer to be $2.4 \times 10^{18}$ photons/s. Water used was distilled over permanganate followed by twice distillations. Although reagents of reagent grade were used without further purification, blank tests for amino acids and nucleic acids were carried out thoroughly for each reagents.

In a typical experiment, $35 \mathrm{ml}$ of $10 \%$ ammonium carbonate aqueous solution $(\mathrm{pH}=8.9)$ was sealed in a quartz ampule and irradiated at $90^{\circ} \mathrm{C}$ for $100 \mathrm{hr}$. The resulting solution was heated at $90^{\circ} \mathrm{C}$ to dryness under the reducing pressure in order to remove the remaining ammonium carbonate and the residue (white) was hydrolyzed at $105^{\circ} \mathrm{C}$ for $48 \mathrm{hr}$ in $6 \mathrm{M} \mathrm{HCl}$. After evaporating the $\mathrm{HCl}$ solution at $90^{\circ} \mathrm{C}$ to dryness, the residue was dissolved with $35 \mathrm{ml}$ of water. Amino acids in the solution were separated by HPLC (SCL-6A, product of Shimazu Co.) equipped with a column of cation exchange resin (Shim-pack ISC-07/S1504Li, a product of Shimazu Co.) and detected based on ninhydrin reaction[13]. Nucleic acid bases were separated by HPLC with an ODS reversed phase column (Shim-pack CLC-ODS, a product of Shimazu Co.) and detected spectrophotometrically at $260 \mathrm{~nm}$.

\section{RESULTS AND DISCUSSION}

When the sample obtained by the UV irradiation of $10 \%$ ammonium carbonate solution for $100 \mathrm{hr}$ at $90^{\circ} \mathrm{C}$ had not been hydrolyzed with $\mathrm{HCl}$ before the HPLC analysis, small peaks corresponding to $1.8 \times 10^{-6} \mathrm{M}$ glycine and $4 \times 10^{-7}$ $\mathrm{M}$ alanine appeared in the chromatogram. Upon hydrolysis of the same sample, however, $1.7 \times 10^{-5} \mathrm{M}$ glycine, $2.8 \mathrm{x}$ $10^{-6} \mathrm{M}$ alanine, $6.0 \times 10^{-6} \mathrm{M}$ serine and $1.4 \times 10^{-6} \mathrm{M}$ aspartic acid were detected. These results suggest that the irradiation product contained polymer(s) which is composed of several kinds of amino acids.

Tables 1 and 2 summarize the concentrations of amino acids in sample solutions obtained under various conditions. 
TABLE 1. Amino acids formed by UV irradiation of aqueous ammonium carbonate (AC) solution $(\mathrm{pH}=8.9)$ at $90^{\circ} \mathrm{C}$

\begin{tabular}{|c|c|c|c|c|c|}
\hline \multirow{2}{*}{$\begin{array}{l}\text { Conc. of } \\
\mathrm{AC}(\%)\end{array}$} & \multirow{2}{*}{$\begin{array}{r}\text { Irradiation } \\
\text { time (hr) }\end{array}$} & \multicolumn{4}{|c|}{ Conc. of Amino acids formed $\left(\times 10^{-7} \mathrm{M}\right)^{\mathrm{a}}$} \\
\hline & & Glycine & Alanine & Serine & Aspartic acid \\
\hline $\begin{array}{r}10 \\
20 \\
5\end{array}$ & 100 & $\begin{array}{r}170 \\
650 \\
83\end{array}$ & $\begin{array}{r}28 \\
175 \\
19\end{array}$ & $\begin{array}{r}6 \\
22 \\
3\end{array}$ & $\begin{array}{r}14 \\
51 \\
8\end{array}$ \\
\hline 10 & $\begin{array}{r}440 \\
20\end{array}$ & $\begin{array}{r}575 \\
22\end{array}$ & $\begin{array}{r}78 \\
3\end{array}$ & $\begin{array}{r}21 \\
\text { N.D. }\end{array}$ & $\begin{array}{r}74 \\
2\end{array}$ \\
\hline $10^{\mathrm{b}}$ & 100 & 21 & N.D. & N.D. & N.D. \\
\hline $10^{c}$ & 1000 & 7 & 2 & N.D. & N.D. \\
\hline $10^{\mathrm{d}}$ & 100 & 18 & 6 & N.D. & N.D. \\
\hline $\mathrm{NH}_{3}+\mathrm{CO}_{2}^{\mathrm{e}}$ & 100 & 148 & 21 & N.D. & 8 \\
\hline
\end{tabular}

a; Results after hydrolysis of irradiation products in $6 \mathrm{M} \mathrm{HCl}$. Results given are concentrations converted to those in irradiated solutions $(35 \mathrm{ml})$. b; Irradiated with light of wave length longer than $250 \mathrm{mn}$. c; Not irradiated. d; Irradiated at $25^{\circ} \mathrm{C}$ instead of $90^{\circ} \mathrm{C}$. e; Aqueous solution prepared bubbling $\mathrm{CO}_{2}$ into 1 $\mathrm{M} \mathrm{NH}_{3}$ until $\mathrm{pH}=8.9$. N.D.; Not detected.

TABLE 2. Amino acids formed by UV irradiation ( $100 \mathrm{hr}$ ) of aqueous ammonium carbonate (AC) solution at $90^{\circ} \mathrm{C}$ under various conditions

\begin{tabular}{|c|c|c|c|c|c|c|}
\hline \multirow{2}{*}{$\begin{array}{l}\text { Conc. of } \\
\mathrm{AC}(\%)\end{array}$} & \multirow{2}{*}{ Reagent coexisted } & \multirow[t]{2}{*}{$\mathrm{pH}$} & \multicolumn{4}{|c|}{ Conc. of Amino acids formed $\left(\times 10^{-7} \mathrm{M}\right)^{\mathrm{a}}$} \\
\hline & & & Glycine & Alanine & Serine & Aspartic acid \\
\hline 10 & none & 8.9 & 170 & 28 & 6 & 14 \\
\hline 10 & none & $\begin{array}{l}9.9 \\
7.0\end{array}$ & $\begin{array}{l}36 \\
59\end{array}$ & $\begin{array}{l}19 \\
23\end{array}$ & $\begin{array}{l}\text { N.D. } \\
\text { N.D. }\end{array}$ & $\begin{array}{r}5 \\
\text { N.D. }\end{array}$ \\
\hline 10 & $\begin{array}{l}0.1 \mathrm{M} \mathrm{MgCl}_{2} \\
0.1 \mathrm{MgSO}_{4} \\
2 \mathrm{M} \mathrm{NaCl}\end{array}$ & 8.9 & $\begin{array}{l}270 \\
293 \\
187\end{array}$ & $\begin{array}{r}120 \\
131 \\
27\end{array}$ & $\begin{array}{r}21 \\
24 \\
9\end{array}$ & $\begin{array}{l}29 \\
32 \\
19\end{array}$ \\
\hline 10 & $\begin{array}{l}0.05 \mathrm{M} \text { oxalic acid } \\
0.05 \mathrm{M} \text { oxamic acid }\end{array}$ & 8.9 & $\begin{array}{l}364 \\
431\end{array}$ & $\begin{array}{r}107 \\
86\end{array}$ & $\begin{array}{l}29 \\
23\end{array}$ & $\begin{array}{l}32 \\
28\end{array}$ \\
\hline \multirow[t]{3}{*}{10} & \multirow{3}{*}{$\begin{array}{l}0.1 \mathrm{M} \mathrm{MgCl}_{2}+ \\
0.05 \mathrm{M} \mathrm{oxalic} \text { acid } \\
0.1 \mathrm{M} \mathrm{MgCl}{ }_{2}+ \\
0.05 \mathrm{M} \mathrm{oxamic} \mathrm{acid} \\
0.1 \mathrm{M} \mathrm{MgCl}_{2}+ \\
0.05 \mathrm{M} \text { oxamide }\end{array}$} & \multirow[t]{3}{*}{8.9} & 1200 & 1230 & 83 & 186 \\
\hline & & & 1430 & 1170 & 72 & 158 \\
\hline & & & 1900 & 1190 & 68 & 161 \\
\hline
\end{tabular}

a; Results after hydrolysis of irradiation products in $6 \mathrm{M} \mathrm{HCl}$. Results given are concentrations converted to those in irradiated solutions $(35 \mathrm{ml})$. N.D.; Not detected.

Data given are those determined after the hydrolysis.

Yields of amino acids increased with the initial concentration of ammonium carbonate (more than proportional) and were nearly proportional to the irradiation time.

The effect of temperature of the solution during the irradiation on the formation of amino acids was remarkable; i.e, the irradiation at $25^{\circ} \mathrm{C}$ yielded negligible amounts of amino acids.

Practically no amino acids were formed by heating for $1000 \mathrm{hr}$ at $90^{\circ} \mathrm{C}$ in the dark. Selecting the range of wave length of the light with the aid of color filter glasses, UV shorter than $250 \mathrm{~nm}$ was found to be effective for the production of amino acids.

In another experiment, $\mathrm{CO}_{2}$ gas was bubbled into $35 \mathrm{ml}$ of $1 \mathrm{M}$ ammonium solution, which had been prepared from gaseous $\mathrm{NH}_{3}$ and distilled water, until $\mathrm{pH}$ of the solution attained to 8.9, and the solution was irradiated for $100 \mathrm{hr}$ at $90^{\circ} \mathrm{C}$. The yields of amino acids and nucleic acid bases were similar to those with ammonium carbonate solution as seen in Table 1. Effects of various conditions during the irradiation were also similar to those with ammonium carbonate solutions.

When ammonium carbonate solutions of which $\mathrm{pH}$ had been adjusted to be 9.9 or 7.0 by adding $\mathrm{LiOH}$ or $\mathrm{HCl}$, respectively, were irradiated, the yields of amino acids were smaller than that at $\mathrm{pH}=8.9$.

The coexistence of $\mathrm{MgCl}_{2}$ or $\mathrm{MgSO}_{4}$ in the ammonium carbonate solution resulted in the increase of the yields of amino acids, especially alanine as can be seen in Table 2 , though the presence of $\mathrm{NaCl}$ up to $2 \mathrm{M}$ gave no effect. 
TABLE 3. Nucleic acid bases formed by UV irradiation of aqueous ammonium carbonate (AC) solution of $\mathrm{pH}=8.9$ at $90^{\circ} \mathrm{C}$ under various conditions

\begin{tabular}{|c|c|c|c|c|}
\hline \multirow[t]{2}{*}{$\begin{array}{l}\text { Conc. of } \\
\mathrm{AC}(\%)\end{array}$} & \multirow[t]{2}{*}{ Reagent coexisted } & \multirow[t]{2}{*}{$\begin{array}{l}\text { Irradiation } \\
\text { time (hr) }\end{array}$} & \multicolumn{2}{|c|}{$\begin{array}{c}\text { Conc. of bases } \\
\text { formed }\left(\times 10^{-7} \mathrm{M}\right)^{\mathrm{a}}\end{array}$} \\
\hline & & & Cytosine & Uracil \\
\hline $\begin{array}{l}10 \\
20\end{array}$ & none & 100 & $\begin{array}{r}40 \\
164\end{array}$ & $\begin{array}{l}18 \\
25\end{array}$ \\
\hline 10 & none & 440 & 127 & 33 \\
\hline $10^{\mathrm{b}}$ & none & 100 & N.D. & N.D. \\
\hline $10^{c}$ & none & 100 & 3 & 2 \\
\hline 10 & $\begin{array}{l}0.1 \mathrm{M} \mathrm{MgCl}_{2} \\
0.05 \mathrm{M} \text { oxalic acid } \\
0.05 \mathrm{M} \text { oxamic acid } \\
0.05 \mathrm{M} \text { oxamide }\end{array}$ & 100 & $\begin{array}{r}68 \\
170 \\
265 \\
814\end{array}$ & $\begin{array}{r}26 \\
81 \\
178 \\
420\end{array}$ \\
\hline
\end{tabular}

a; Results after hydrolysis of irradiation products in $6 \mathrm{M} \mathrm{HCl}$. Results given are concentrations converted to those in irradiated solutions $(35 \mathrm{ml})$. b; Not irradiated. c; Irradiation at $25^{\circ} \mathrm{C}$ instead of $90^{\circ} \mathrm{C}$. N.D.; not detected.

Nucleic acid bases in the sample which had been prepared irradiating $10 \%$ ammonium carbonate for $100 \mathrm{hr}$ at $90^{\circ} \mathrm{C}$ were determined by HPLC. Three small peaks appeared in the chromatogram when the sample had not been hydrolyzed. After the hydrolysis with $6 \mathrm{M} \mathrm{HCl}$, peaks at positions corresponding to cytosine and uracil grew remarkably and $4.0 \times 10^{-6} \mathrm{M}$ cytosine and $1.8 \times 10^{-6} \mathrm{M}$ uracil were found. Effects of various conditions during the irradiation on yields of the bases were similar to those observed for amino acids, as seen in Table 3.

Since oxalic acid, oxamic acid or oxamide were assumed to be the possible intermediates to form amino acids and/or nucleic acid bases from ammonium carbonate which is composed of ammonium carbamate and ammonium hydrogencarbonate, $0.05 \mathrm{M}$ oxalic acid, oxamic acid or oxamide were added into solutions before the irradiation and the irradiation was carried out. Then, the yields of amino acids and nucleic acid bases in the irradiated solutions were investigated. As clearly seen in Tables 2 and 3, the presence of the intermediates facilitated the formation of amino acids and nucleic acid bases. The yields of amino acids were nearly proportional to concentrations of the intermediates. The yields of nucleic acid bases also increased with the increase of concentrations of the intermediates, though the reproducibility was fairly poor. When $0.05 \mathrm{M}$ oxamic acid in the absence of ammonium carbonate was irradiated, amounts of amino acids and nucleic acid bases formed were negligible even in the presence of $0.1 \mathrm{M} \mathrm{MgCl}_{2}$.

In order to confirm the formation of oxalic acid, oxamic acid and/or oxamide as the intermediates, a solution containing $10 \%$ ammonium carbonate and $0.1 \mathrm{M} \mathrm{MgCl}_{2}$ had been irradiated for $100 \mathrm{hr}$ at $90^{\circ} \mathrm{C}$ and, after the hydrolysis with $6 \mathrm{M} \mathrm{HCl}$, the resulting solution was analyzed by HPLC equipped with an ODS reversed phase column (Shim-pack CLC-ODS) and spectrophotometer for the detection at $210 \mathrm{~nm}$. The eluent employed was $0.01 \mathrm{M}$ in trin-octylamine and $0.002 \mathrm{M}$ in phosphoric acid $\left(\mathrm{pH}=6.3\right.$, flow- rate; $\left.0.8 \mathrm{ml} \mathrm{min}^{-1}\right)$. Oxalic acid, oxamic acid and oxamide found were $1.4 \times 10^{-4}, 1.3 \times 10^{-4}$ and less than $10^{-6} \mathrm{M}$, respectively. The voltammetric determination of oxalic acid and oxamic acid based on the oxidation waves at a stationary platinum electrode (cf. Fig. 2) supported the results by HPLC.<smiles>NOC(=O)O</smiles>

\section{Ammonium hydrogencarbonate}

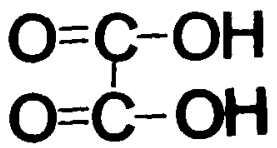

Oxalic acid

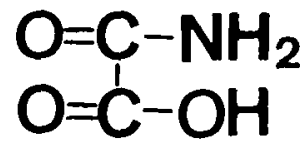

Oxamic acid<smiles>NC(=O)O[NH3+]</smiles>

\author{
Ammonium \\ carbamate
}

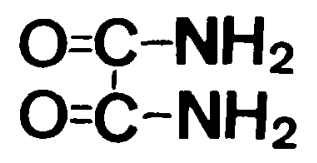

Oxamide

Fig. 1 Ammonium hydrogencarbonate, ammonium carbonate, oxalic acid, oxamic acid and oxamide. 


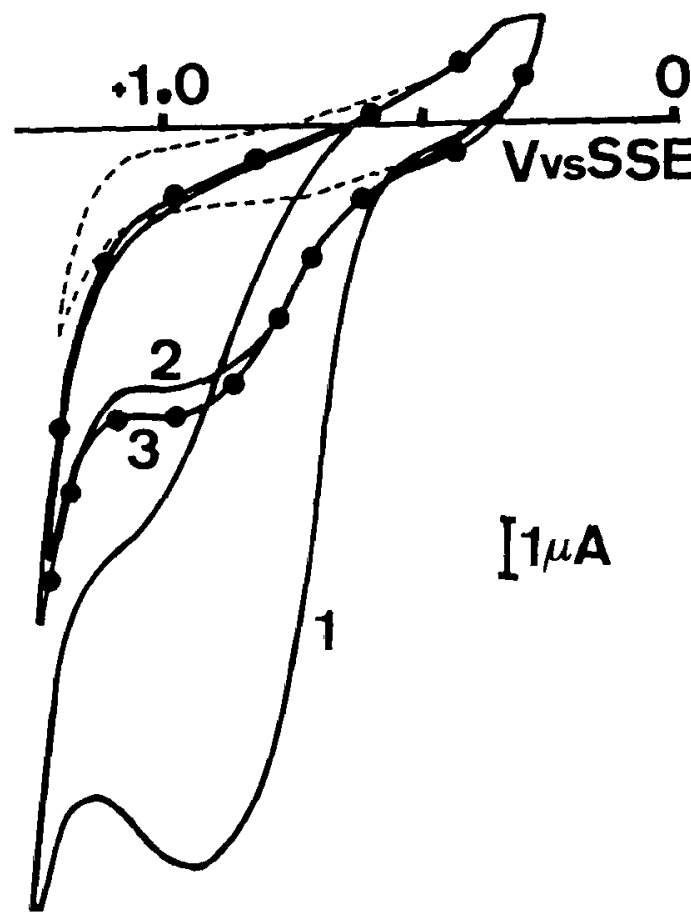

Fig. 2 Voltammograms of oxalic acid, oxamic acid and the irradiated ammonium carbonate solution at a stationary platinum disk electrode $(5 \mathrm{~mm} \phi)$. Supporting electrolyte: $0.5 \mathrm{M} \mathrm{Li}_{2} \mathrm{SO}_{4}+0.25 \mathrm{M} \mathrm{KH}_{2} \mathrm{PO}_{4} ;$ Scan-rate: $0.5 \mathrm{mVs}^{-1}$; 1: $3 \times 10^{-3} \mathrm{M}$ oxalic acid; $2: 6 \times 10^{-3} \mathrm{M}$ oxamic acid; 3: the sample obtained after irradiation of $10 \%$ ammonium carbonate solution in the presence of $0.1 \mathrm{M} \mathrm{MgCl}_{2}$ for $100 \mathrm{hr}$ at $90^{\circ} \mathrm{C}$ followed by 5 times concentration; residual current.

Yanagawa et al.[12] reported that $\mathrm{N}$-acylamino acids were formed from $\alpha$-oxo acids and ammonia in aqueous medium by thermal energy and $\mathrm{N}$-acylamino acids gave $\alpha$-amino acids and carboxylic acids such as oxalic acid after 6 $\mathrm{M} \mathrm{HCl}$ hydrolysis. In connection with the chemical evolution, they assumed the formation of formaldehyde at the initial stage from $\mathrm{CO}$ [14], $\mathrm{CO}_{2}$ [15] and water by UV irradiation, or from $\mathrm{CH}_{4}$ and water by electric discharge[16]. Formaldehyde forms $\alpha$-oxo acids through aldol condensation.

In the present work, the formation of amino acids and nucleic acid bases from $\mathrm{CO}_{2}$ and $\mathrm{NH}_{3}$ in water by UV irradiation at high temperature has been clearly demonstrated, carboxylic acids such as oxalic acid or oxamic acid have been recognized as important intermediates, and $\mathrm{Mg}^{2+}$ has been proved to be one of effective catalysts for the formation of amino acids and nucleic acid bases.

Finally, as ammonium carbonate is composed of ammonium carbamate and ammonium hydrogen carbonate and $\mathrm{CO}_{2}$ dissolved together with $\mathrm{NH}_{3}$ in water exists as ammonium hydrogen carbonate at $\mathrm{pH}=\mathbf{8}$ to 9 , we consider that the investigation on photochemical reactions of hydrogen carbonate at high temperature may endow much information on the processes involved in the formation of amino acids and nucleic acid bases.

\section{REFERENCES}

1. S.L. Miller, Science, 117,528 (1953).

2. S.L. Miller and L.E. Orgel, The Origin of Life on the Earth, Prentice-Hall, New Jersey, 1974.

3. Data of Geochemistry, Volcanic Emanations, Geochemical Survey Professional Paper, U.S. Government Printing Office, Washington, C.C., 1963.

4. W.D. Metz, Science, 194,924 (1976).

5. H.D. Holland, Petrologic Studies - A Volume to Honor A. F. Buddington, Geological Society of America, Colorado, p. 447, 1962

6. S. Matsuo, Origin of Life, Japan Sci. Soc. Press, Tokyo, p. 27, 1978.

7. R. Paschke, R.W.H. Chang and D. Young, Science, 125, 881 (1957).

8. P.H. Abelson, Science, 124,935 (1956).

9. J. Oro', A. Kimball, R. Fritz and F. Master, Arch. Biochem. Biophys., 85,115 (1959).

10. F. Egami, J. Mol. Evol., 4, 113 (1974).

11. H. Hatanaka and F. Egami, Bull. Chem. Soc. Jpn., 50, 1147 (1977).

12. H. Yanagawa, Y. Makino, K. Sato, M. Nishizawa and F. Egami, Origins of Life, 14, 163 (1984) and references cited therein.

13. T. Hori and S. Kihara, Fresenius Z. Anal. Chem., 330, 627 (1988).

14. A. Bar-run and H. Hartman, Origins of Life, 9,93 (1978).

15. W. Groth and H. Suess, Naturwiss, , 26, 77 (1938).

16. S.L. Miller, J. Am. Chem. Soc., 77, 2351 (1955). 